www.jmscr.igmpublication.org

Impact Factor 5.84

Index Copernicus Value: 83.27

ISSN (e)-2347-176x ISSN (p) 2455-0450

crossref DOI: _https://dx.doi.org/10.18535/jmscr/v5i5.53

\begin{abstract}
Journal Of Medical Science And Clinical Research
IGM Publication

An Official Publication of IGM Publication
\end{abstract}

\title{
Low Serum Zinc Level- a Possible Marker of Severe Pneumonia
}

\author{
Authors \\ Dr N. Kumar, MD, Dr S. Jayaprakash, MD, Dr D. Kavitha, MD \\ Coimbatore Medical College Hospital
}

\begin{abstract}
Pneumonia is one of the main causes of death in under five children ${ }^{1}$. Zinc deficiency is associated and may lead to the cause of pneumonia. In our region we have no data about serum zinc levels in under five children and in the hospitalized children with pneumonia. Aim of the study is to compare the serum zinc levels among children 6 months to 60 months of age hospitalized with severe pneumonia with the same age matched controls. This could give us an idea about the necessary for zinc supplementation in under five children and also the need for serum zinc level estimation in children with severe pneumonia as a routine investigation in pneumonia management. This is a case control study conducted at the department of pediatrics, Coimbatore Medical College Hospital from July 2014-June2015. All hospitalized children 6 to 60 months of age with severe pneumonia (both bronchopneumonia and lobar pneumonia) as per WHO criteria, with $x$-ray finding are selected. Children with clinical features of congenital zinc deficiency, PEM grade III and IV, immunodeficiency, ADD, hospital acquired pneumonia; on zinc containing supplements were excluded. Age matched healthy controls included for comparison. Children with clinical features of congenital zinc deficiency, PEM grade III and IV, on zinc containing supplemental were excluded in control group. 50 cases and 50 controls are included for study. Serum zinc levels are estimated using atomic absorption spectrometry and compared. All children were from lower socioeconomic class. Zinc level - "cut off value taken as "For males and females less than 10 years in South Asian population is $65 \mathrm{Kg} / \mathrm{dl}$. All data were analyzed with a statistical software package (SPSS, version 16.0 for windows)". About $80 \%$ of children with severe pneumonia had low serum zinc levels $(P=0.001)$. Slight preponderance of male is seen in the study group $(p>0.5)$. No association between low serum zinc level and variables like age, sex, place of residence, duration of breast feeding, time of weaning, preterm/twin pregnancy, calorie and protein gap, developmental milestones, immunization history and family history of seizures were noted. There was strong association between low serum zinc level and mixed feeds. So exclusive breast feeding seems to be protective against zinc deficiency. Low birth weight has strong association with low serum zinc level. Low serum zinc levels have significant association with febrile seizures. Increased frequency of illness in past 6 months is associated with low serum zinc levels. Strong association of low serum zinc levels with vegetarian diet. Non vegetarian diet is protective against zinc deficiency. As $68 \%$ of study population is less than 2 years of age, intake of tubers does not have significant association with low serum zinc level. In this study low serum zinc is associated with tachypnea, increased respiratory distress and low oxygen saturation. Low serum zinc level is associated with leucocytosis significantly and this may be due to increased susceptibility to infection. Low serum zinc level does not have significant association with type of pneumonia that is lobar pneumonia or bronchopneumonia. There is no association between low serum zinc level and hospital stay. In conclusion, children with severe pneumonia have low serum zinc levels and thus "Low serum zinc level is a marker of severe pneumonia. Also lower the serum zinc level the higher the respiratory distress and associated significantly with low oxygen saturation.
\end{abstract}

Keywords: Serum, Zinc level, severe pneumonia

\section{INTRODUCTION}

Pneumonia defined as inflammation of the lung parenchyma, is the leading cause of death globally among children younger than age $5 \mathrm{yr}$, accounting for an estimated 1.2 million (18\% total) deaths annually ${ }^{1}$. The incidence of pneumonia 10 times 
more and the childhood mortality due to this disease is two thousand times more comparing to other diseases. In the world three fourths of the deaths from pneumonia occurs in fifteen countries. Pneumonia is the single largest infectious cause of death in children worldwide. Pneumonia affects children and families everywhere, but is most prevalent in South Asia and sub-Saharan Africa. The WHO 2014 November report says that ${ }^{1}$ "pneumonia is the leading infectious cause of death in children worldwide, accounting for $15 \%$ of all deaths of children under 5 years old. Pneumonia killed an estimated 935, 000 children under the age of five in 2013. Throughout the world the mortality from pneumonia is declined by 97\%. In 2007, pneumonia accounted for $2 \%$ of all the deaths of children less than 5 years of age, than $9 \%$ at 1970 . The reduction in the incidence is mainly due to the invention of the newer antibiotics, good medical care and the vaccines. Pneumonia can be caused by viruses, bacteria or fungi pneumonia can be prevented by immunization, adequate nutrition and by addressing environmental factors. Haemophilus influenzae type $b$ was the frequent etiology for the bacterial pneumonia in the young children. But after the use of the effective vaccine against this, there is significant reduction of this disease. The measles vaccine reduced significant amount of deaths due to post measles pneumonia. The infrastructure in the rural and the remotes areas of the developing countries improved and the access to the medical facilities were better in the developing countries like India. The role of the two important vaccines like the pneumococcal conjugate vaccine and the flu vaccine is very important in reducing the pneumonia related deaths in the recent past years. Pneumonia caused by bacteria can be treated with antibiotics, but only one third of children with pneumonia receive the antibiotics they need. Pneumonia is a form of acute respiratory infection that affects the lungs ${ }^{2}$. The lungs are made up of small sacs called alveoli, which fill with air when a healthy person breathes. When an individual has pneumonia, the alveoli are filled with pus and fluid, which makes breathing painful and limits oxygen intake $^{2}$.

There are many studies which show that zinc deficiency is associated and may lead to the cause of pneumonia. In our region we have no data about serum zinc levels in under five children and in the hospitalized children with pneumonia. So this study aims to find them. This may give us an idea about necessary for zinc supplementation in under five children and also the need for serum zinc level estimation in children with severe pneumonia as a routine investigation in pneumonia management. Children can be protected from pneumonia; it can be prevented with simple interventions, and treated with low-cost, low-tech medication and care. Zinc is an essential trace element ${ }^{3}$ required for maintaining intestinal cells, bone growth, and immune function. Children who are living in low-income settings are often undernourished and zinc deficient. Severe zinc deficiency has been associated with stunting of growth, impaired immunity, skin disorders, learning disabilities and anorexia". "Studies of zinc supplementation for the treatment or improved management of acute lower respiratory tract infections, including pneumonia have had mixed results. Zinc supplementation in combination with oral rehydration solution has already formed the basis of the WHO/UNICEF recommendation for use in the management of children with diarrhea. Zinc is an "essential mineral that is naturally present in some foods, added to others and also available as a dietary supplement. Zinc is involved in many aspects of metabolism of the human cells. It is necessary for the catalytic activity of more than three hundred enzymes. Also it plays a very important role in the immune functions of the human body and has many roles in protein synthesis and wound healing. Also it is very important in the process DNA synthesis and in cell division. Zinc also helps the normal growth and development at and during pregnancy and childhood adolescence and adults ${ }^{6}$. It is required for the special sense organs like tongue and the nose for taste and smell. As there is no separate storage system for zinc in 
our body. Hence daily intake of zinc is required to maintain a steady state in our body functions.

The recommendations for intake of zinc are given in the Dietary Reference Intakes developed by the Food and Nutrition Board at the Institute of Medicine of the National Academies ${ }^{6}$. The Zinc nutritional status is difficult to estimate correctly using laboratory tests ${ }^{29}$, because zinc is distributed as a component of various proteins and nucleic acids. Plasma or serum zinc levels are the most commonly used indices for evaluating zinc deficiency. But these levels do not necessarily reflect cellular zinc status because of the tight homeostatic control mechanisms. Clinical effects of zinc deficiency can be present with normal laboratory values ${ }^{28}$. Physicians should consider risk factors like inadequate caloric intake, alcoholism and gastrointestinal diseases. Though the zinc deficiency occurs due to various reasons, the need to correct is important as many studies show higher death rate with children affected with pneumonia is associated with low level of zinc. It is obvious if we have data regarding prevalence of zinc deficiency it will be useful to treat that. Also the zinc content in soil is not the same throughout the world. So many factors are involved in zinc deficiency and its relevance with various diseases. The second most important among them is pneumonia. The WHO has devised a multifactorial approach in management of pneumonia now for effective treatment zinc supplementation is also suggested ${ }^{1}$. Knowing the deficiency status is essential for treatment of pneumonia, only then adequate dose of zinc therapy can be instituted.

Various studies supporting zinc supplementation in zinc deficient population which given in adequate doses prevents pneumonia. Also mortality associated with pneumonia can also be reduced by this effort. There is no study detailing the level of zinc deficiency and severe pneumonia in our region. This study aims at finding out the correlation between levels of zinc with severe pneumonia. This study might throw a light on need for prophylactic zinc supplementation in under five children and the need to estimate serum zinc level in children with pneumonia as a routine.Aim of the study is to compare the serum zinc levels among children 6 months to 60 months of age hospitalized with severe pneumonia with the same age matched controls. Objectives are: To find serum zinc level in the hospitalized children 6 to 60 months of age with severe pneumonia, to find serum zinc levels in the age matched controls, to find the relationship between the serum zinc level and severe pneumonia

\section{MATERIALS AND METHODS}

This is a case control study conducted at the department of pediatrics, Coimbatore Medical College Hospital from July 2014-June2015. All hospitalized children 6 to 60 months of age with severe pneumonia (both bronchopneumonia and lobar pneumonia) as per WHO criteria, with x-ray finding are selected.. Children with clinical features of congenital zinc deficiency, Patients with PEM grade III and IV (IAP classification), Patients with clinical features suggestive of immunodeficiency, Patients with acute diarrheal diseases, patients with hospital acquired pneumonia, children taking zinc containing supplements were excluded. Age matched healthy controls included for comparison. Children with clinical features of congenital zinc deficiency, children with PEM grade III and IV (IAP classification), and children taking zinc containing supplemental were excluded in control group. 50 cases and 50 controls are included for study. Sample size calculation formula: $n=t^{2} \times p(1-$ p) $/ \mathrm{m}^{2}$ here, $\mathrm{n}=$ required sample size, $\mathrm{T}=$ confidence level of 95\%. p = Expected Frequency of the Factor under Study $-1.6 \% \mathrm{M}=$ margin of error of $5 \%$ (Standard value of 0.05 ), $\mathrm{n}=97$ '. The sample is further increased by $5 \%$ to account for contingencies such as non-response or recording error. $\mathrm{n}+5 \%=97 \times 5 \%=100$ [both groups] each group - 50+ 50. Serum zinc levels are estimated in them. Then age, sex and nutrition matched controls are selected from outpatient department and their serum zinc levels are estimated. Then the relationship between serum zinc levels and severe pneumonia is studied. All children included in this study are from lower socioeconomic class as per 


\section{JMSCR Vol||05||Issue||05||Page 21554-21570||May}

modified kuppusamy scale. Prior consent is obtained from parents of the children included in this study. Admitted patients included in the study are evaluated by taking detailed history as per the proforma attached. Blood sample is taken from them. Serum zinc levels are estimated using atomic absorption spectrometry. Their course in the hospital, duration of stay and their outcomes are noted. Age matched controls for the cases are selected from the pediatric outpatient department. Blood from them is tested for serum zinc levels by the same method. For estimation of zinc $2 \mathrm{ml}$ of blood collected using 22 gauge steel needle in a dry tube and allowed to be clotted and serum separates and then sent for processing or stored in 2 to 8 degree in refrigerator for maximum of 48 hours and sent to private lab for processing. The serum zinc level is estimated using Atomic absorption spectrometer. Zinc level - "cut off value taken as "For males and females less than 10 years in South Asian population is $65 \mathrm{Kg} / \mathrm{dl}$. The qualitative variables as expressed in frequency and percentage. A Chi Square test was used to assess differences in categorical variables between groups. Odds ratio was used to assess the variables. $\mathrm{P}$ value of $<0.05$ using a two tailed test was taken as being of significance for all statistical tests. All data were analyzed with a statistical software package (SPSS, version 16.0 for windows)

\section{RESULTS}

\begin{tabular}{|c|c|c|c|c|}
\hline \multirow[t]{2}{*}{ AGE } & & ENDER & TOTAL & $(\%)$ \\
\hline & MALE & FEMALE & & \\
\hline$<1 \mathrm{yr}$ & 16 & 12 & 28 & $28 \%$ \\
\hline $1-2 \mathrm{yr}$ & 22 & 18 & 40 & $40 \%$ \\
\hline$>2-5 \mathrm{yr}$ & 14 & 18 & 32 & $32 \%$ \\
\hline TOTAL & 52 & 48 & 100 & \\
\hline
\end{tabular}

$28 \%$ of study population is <1 year and $40 \%$ is between 1-2 years. So a total of $68 \%$ of study population is below 2 years. Only $32 \%$ is between
2-5 years. In this study group 52 are male and 48 are female. There is no statistical significance in sex distribution.

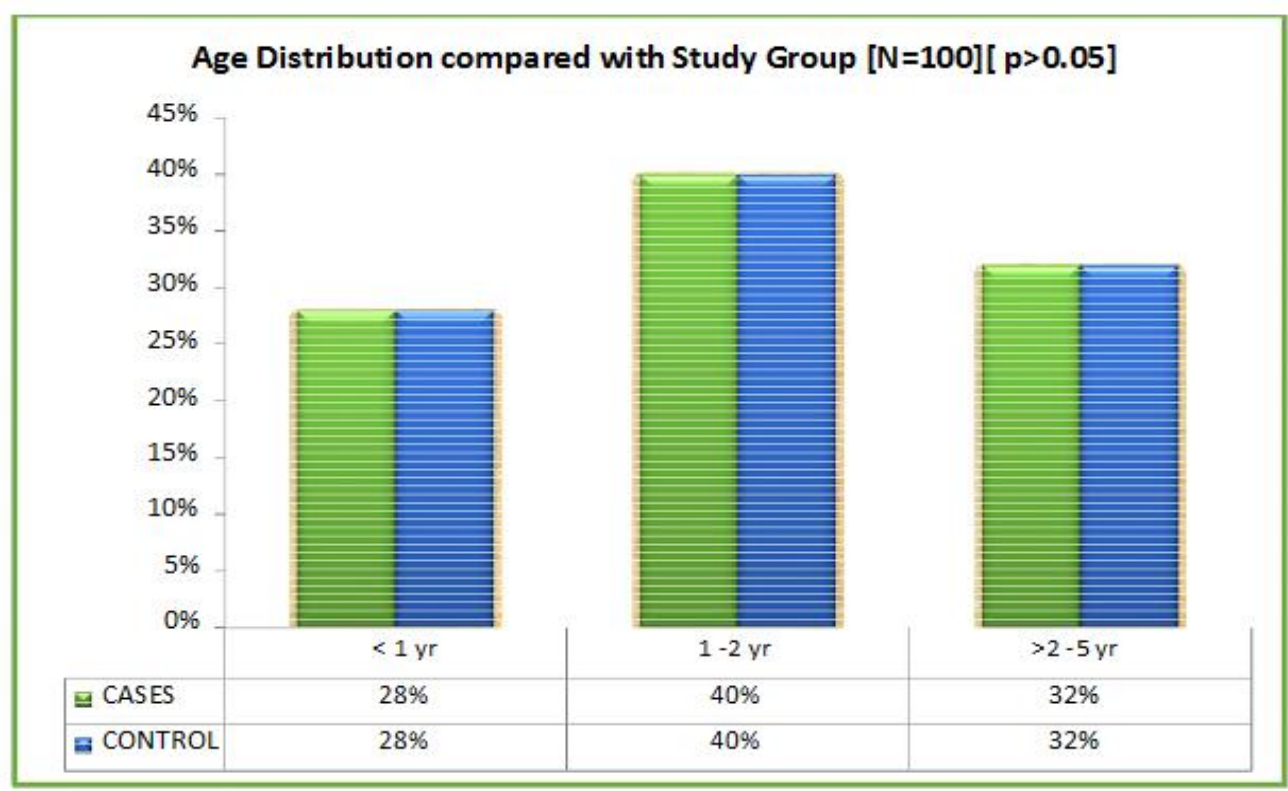




\section{SERUM ZINC}

\begin{tabular}{|l|c|} 
Sr.Zinc & $\mathbf{n}$ \\
\hline$>65 \mathrm{mcg}$ & 50 \\
\hline $50-64 \mathrm{mcg}$ & 18 \\
\hline$<50 \mathrm{mcg}$ & 32 \\
\hline Total & 100 \\
\hline
\end{tabular}

50 children had serum zinc levels above $65 \mathrm{mc} \mathrm{g} / \mathrm{dl}$ and 50 children below this cut off. Among the cases 40 children had serum zinc levels below $65 \mathrm{mcg} / \mathrm{dl}$ and 10 children above $65 \mathrm{mcg} / \mathrm{dl}$. Among the controls 40 children had serum zinc levels above $65 \mathrm{mcg} / \mathrm{dl}$ and 10 children below $65 \mathrm{mcg} / \mathrm{dl}$

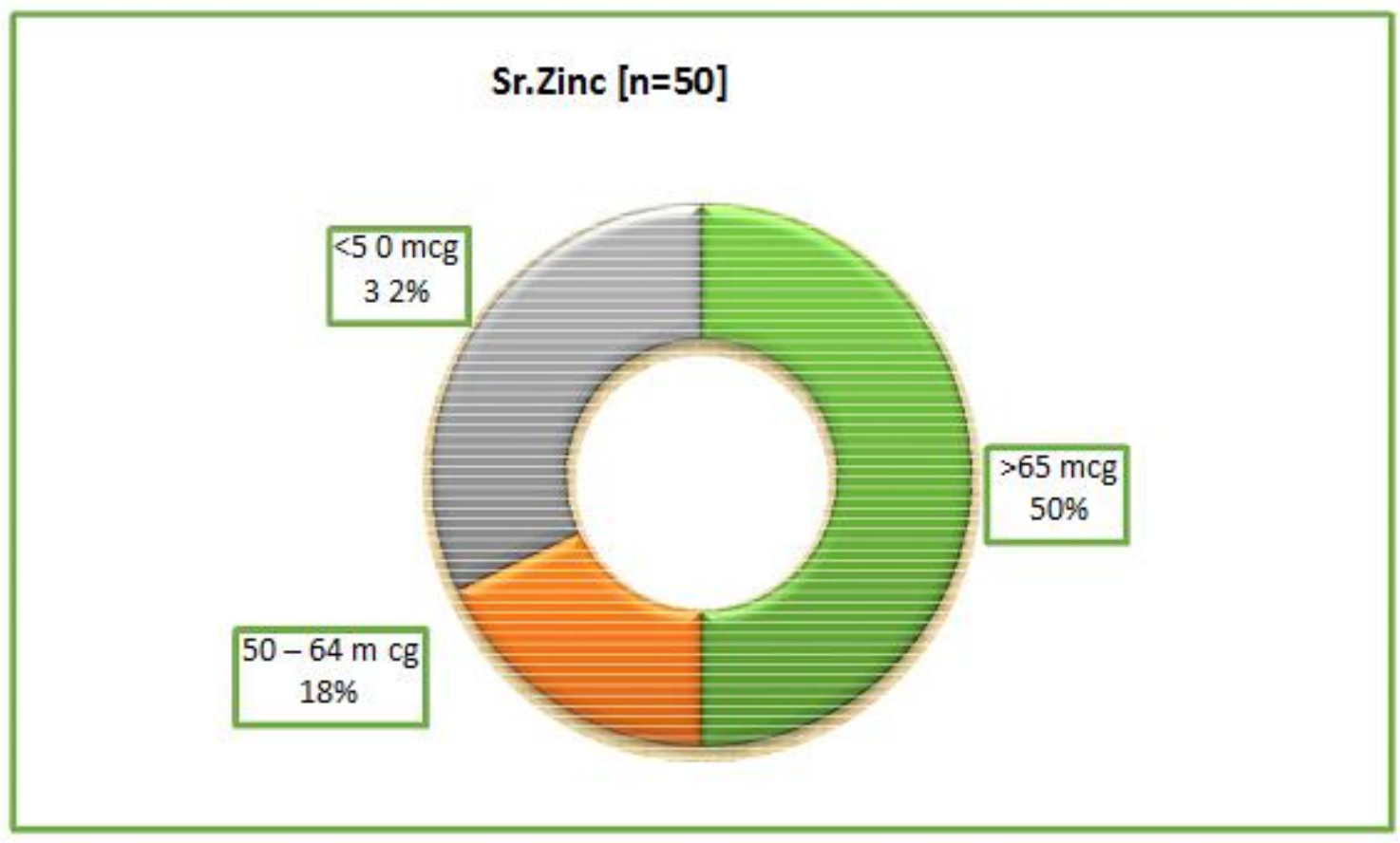

\section{SERUM ZINC LEVEL IN STUDY GROUP}

\begin{tabular}{|l|c|c|c|c|}
\hline \multirow{2}{*}{ Sr.Zinc } & \multicolumn{2}{|c|}{ STUDY GROUP } & \multirow{2}{*}{ TOTAL } & \multirow{2}{*}{$(\%)$} \\
\cline { 2 - 3 } & CASES & CONTROL & & \\
\hline LOW & 40 & 10 & 50 & $50 \%$ \\
\hline NORMAL & 10 & 40 & 50 & $50 \%$ \\
\hline TOTAL & 50 & 50 & 100 & \\
\hline
\end{tabular}

This low serum zinc levels being low in cases is statistically significant with $\mathrm{p}$ value $<0.001$. This shows that serum zinc level is low in severe pneumonia which is very significant 


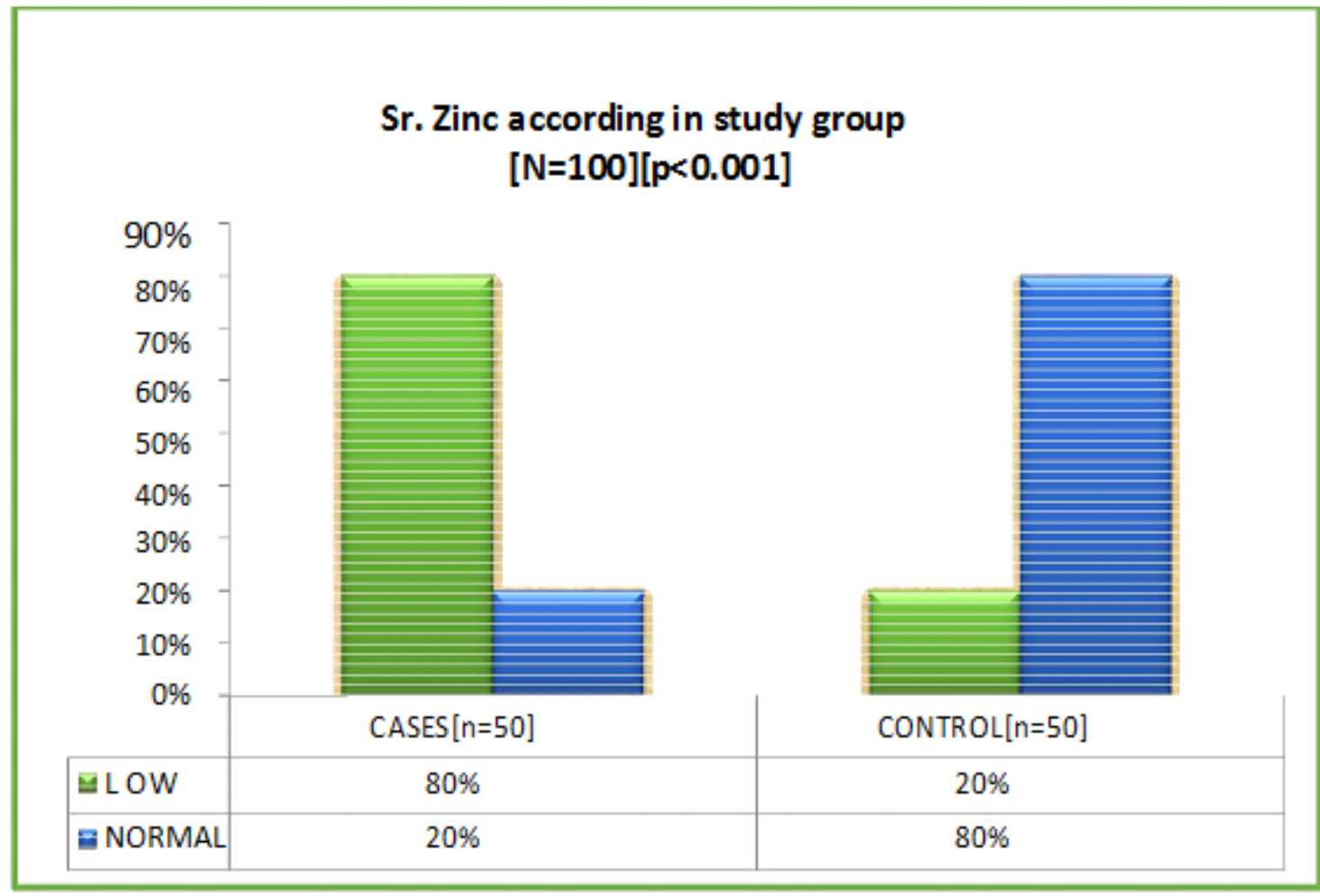

\section{ASSOCIATI ON OF MIXED FEEDS WITH SERUM ZINC LEVELS IN STUDY GROUP}

\begin{tabular}{|c|c|c|c|c|c|c|}
\hline \multirow{2}{*}{$\begin{array}{l}\text { ST UDY } \\
\text { GROUP }\end{array}$} & \multirow{2}{*}{ Mixed Feeds } & \multicolumn{2}{|c|}{ Serum Zinc Level } & \multirow{2}{*}{ Total } & \multirow{2}{*}{$(\%)$} & \multirow{2}{*}{ Sig } \\
\hline & & LOW & NORMAL & & & \\
\hline \multirow{5}{*}{ CASES } & CO WS MILK & 17 & 3 & 20 & $40 \%$ & \\
\hline & FORMULA MILK & 6 & 0 & 6 & $12 \%$ & $>0.05$ \\
\hline & BOTH & 2 & $\overline{0}$ & 2 & $4 \%$ & \\
\hline & NIL & 15 & 7 & 22 & $44 \%$ & \\
\hline & Total & 40 & 10 & 50 & $100 \%$ & \\
\hline \multirow{4}{*}{ CONTROL } & CO WS MILK & 6 & 2 & 8 & $16 \%$ & \\
\hline & FORMULA MILK & 0 & 4 & 4 & $8 \%$ & \\
\hline & NIL & 4 & 34 & 38 & $76 \%$ & $<0.05$ \\
\hline & Total & 10 & 40 & 50 & $100 \%$ & \\
\hline
\end{tabular}

There is statistically significant association between serum zinc level and mixed feeds 


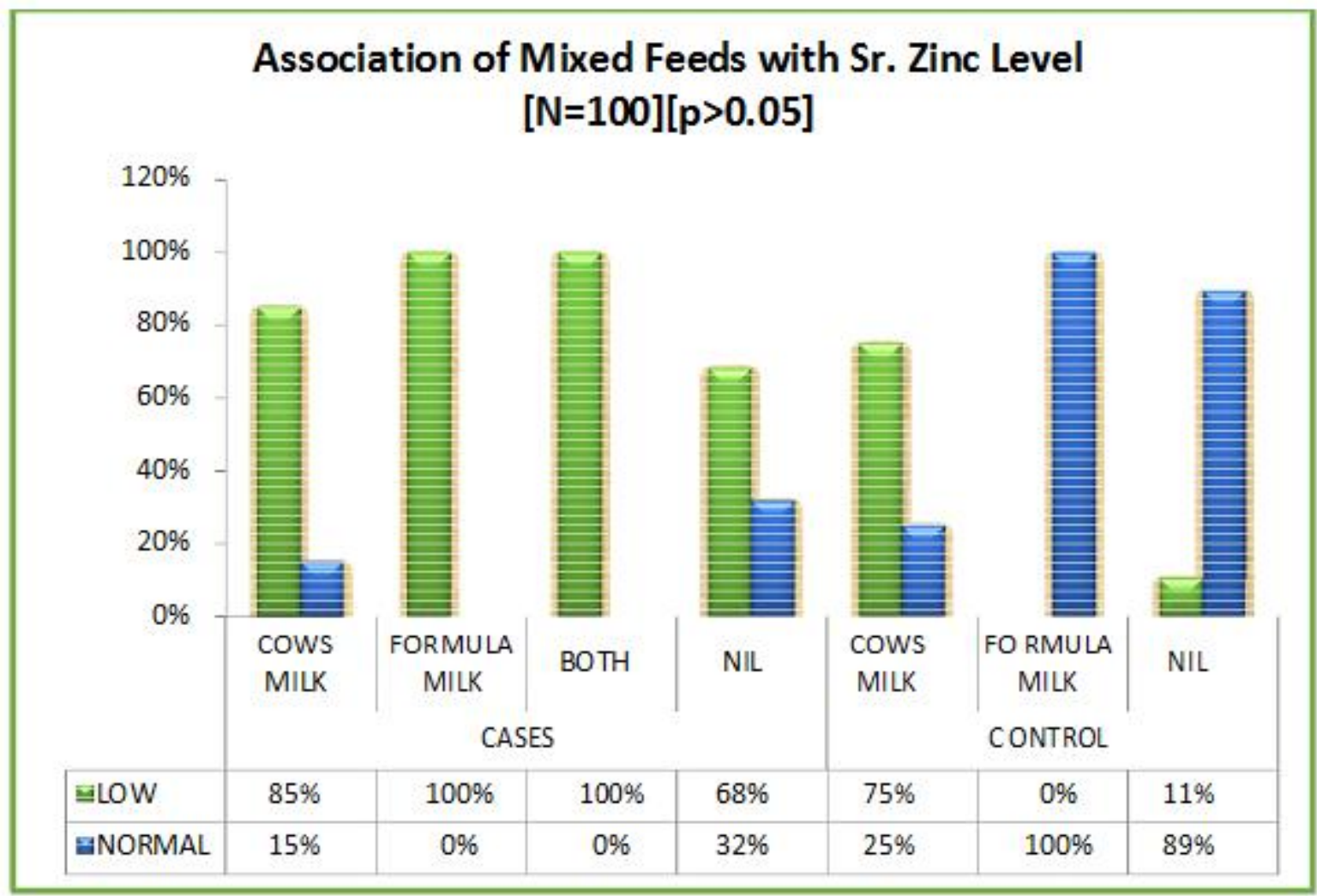

ASSOCIATI ON OF BIRTH WEIGHT WITH SE RUM ZINC LEVELS IN STUDY GROUP

\begin{tabular}{|c|c|c|c|c|c|c|}
\hline \multirow{2}{*}{$\begin{array}{l}\text { STUDY } \\
\text { GROUP }\end{array}$} & \multirow{2}{*}{$\begin{array}{c}\text { Birth } \\
\text { Weight }\end{array}$} & \multicolumn{2}{|c|}{ Serum Zinc Level } & \multirow{2}{*}{ Total } & \multirow{2}{*}{$(\%)$} & \multirow{2}{*}{ Sig } \\
\hline & & LOW & NORMAL & & & \\
\hline \multirow{3}{*}{ CASES } & $<2.5 \mathrm{KG}$ & 11 & 0 & 11 & $22 \%$ & \\
\hline & $>2.5 \mathrm{KG}$ & 29 & 10 & 39 & $78 \%$ & $<0.05$ \\
\hline & Total & 40 & 10 & 50 & $100 \%$ & \\
\hline \multirow{3}{*}{ CONTROL } & $<2.5 \mathrm{KG}$ & 2 & 1 & 3 & $6 \%$ & \\
\hline & $>2.5 \mathrm{KG}$ & 8 & 39 & 47 & $94 \%$ & $<0.05$ \\
\hline & Total & 10 & 40 & 50 & $100 \%$ & \\
\hline
\end{tabular}

There is statistically significant association between serum zinc level and birth weight. 


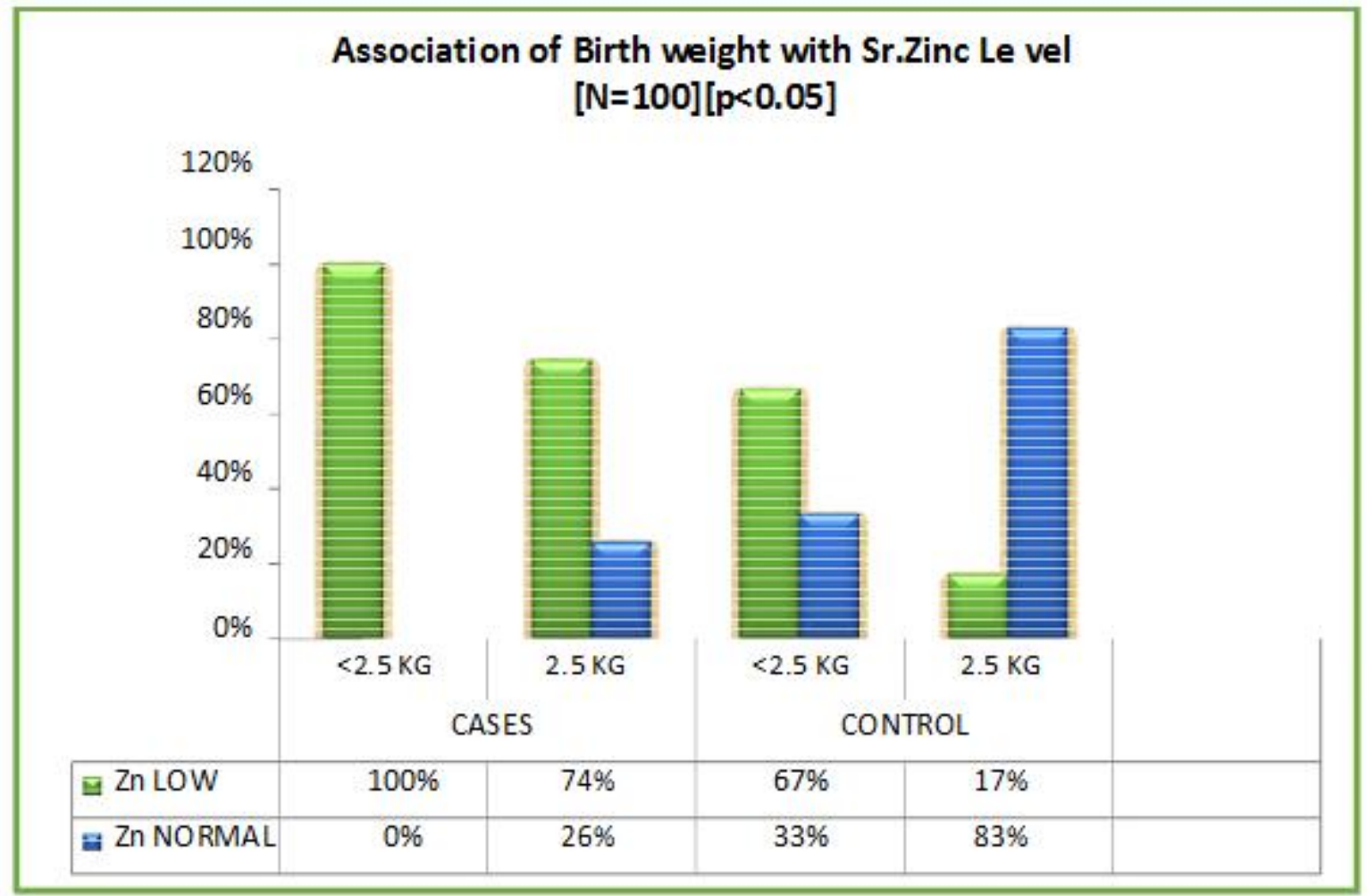

ASSOCIATION OF FEBRILE SEIZURE WITH LOW SERUM ZINC LEVELS IN STUDY GROUP

\begin{tabular}{|c|c|c|c|c|c|c|}
\hline \multirow{2}{*}{$\begin{array}{l}\text { STUDY } \\
\text { GROUP }\end{array}$} & \multirow{2}{*}{$\begin{array}{l}\text { Febrile } \\
\text { Seizure }\end{array}$} & \multicolumn{2}{|c|}{ Serum Zinc Level } & \multirow[b]{2}{*}{ Total } & \multirow[b]{2}{*}{$(\%)$} & \multirow[b]{2}{*}{ Sig } \\
\hline & & Low & Normal & & & \\
\hline \multirow{3}{*}{ CASES } & Present & 7 & 0 & 7 & $14 \%$ & \\
\hline & Absent & 33 & 10 & 43 & $86 \%$ & $<0.05$ \\
\hline & Total & 40 & 10 & 50 & $100 \%$ & \\
\hline \multirow{3}{*}{ CONTROL } & Present & 1 & 0 & 1 & $2 \%$ & \\
\hline & Absent & 9 & 40 & 49 & $98 \%$ & $<0.05$ \\
\hline & Total & 10 & 40 & 50 & $100 \%$ & \\
\hline
\end{tabular}

There is statistically significant association between low serum zinc level and febrile seizure. 


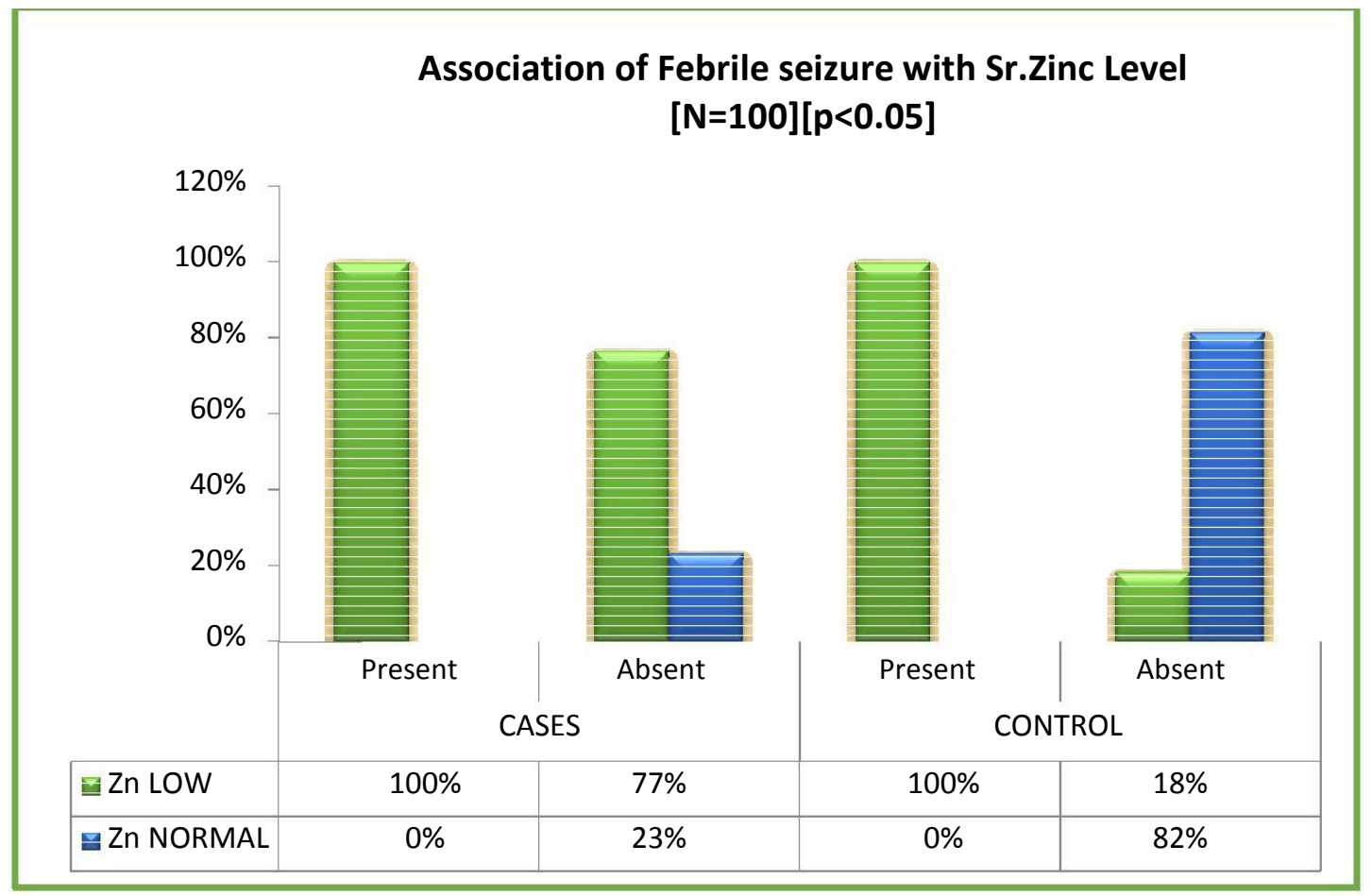

\section{ASSOCIATION OF NUMBER OF ILLNESSES WITHIN LAST 6 MONTHS WITH LOW SERUM ZINC} LEVELS IN STUDY GROUP

\begin{tabular}{|c|c|c|c|c|c|c|c|}
\hline \multirow{2}{*}{$\begin{array}{l}\text { STUDY } \\
\text { GROUP }\end{array}$} & \multirow{2}{*}{$\begin{array}{c}\text { No of } \\
\text { illne ss in } \\
\text { last } 6 \text { mths }\end{array}$} & \multicolumn{2}{|c|}{ Serum zinc level } & \multirow[b]{2}{*}{ Low } & \multirow[b]{2}{*}{ Tot al } & \multirow[b]{2}{*}{$(\%)$} & \multirow[b]{2}{*}{ Sig } \\
\hline & & Normal & Mild low & & & & \\
\hline \multirow{4}{*}{ CASES } & One time & 10 & 9 & 24 & 43 & $86 \%$ & \\
\hline & Two times & 0 & 4 & 1 & 5 & $10 \%$ & $<0.05$ \\
\hline & NIL & 0 & 0 & 2 & 2 & $4 \%$ & \\
\hline & Total & 10 & 13 & 27 & 50 & $100 \%$ & \\
\hline \multirow{2}{*}{ CONTROL } & NIL & 40 & 5 & 5 & 50 & $100 \%$ & \\
\hline & Total & 40 & 5 & 5 & 50 & $100 \%$ & \\
\hline
\end{tabular}




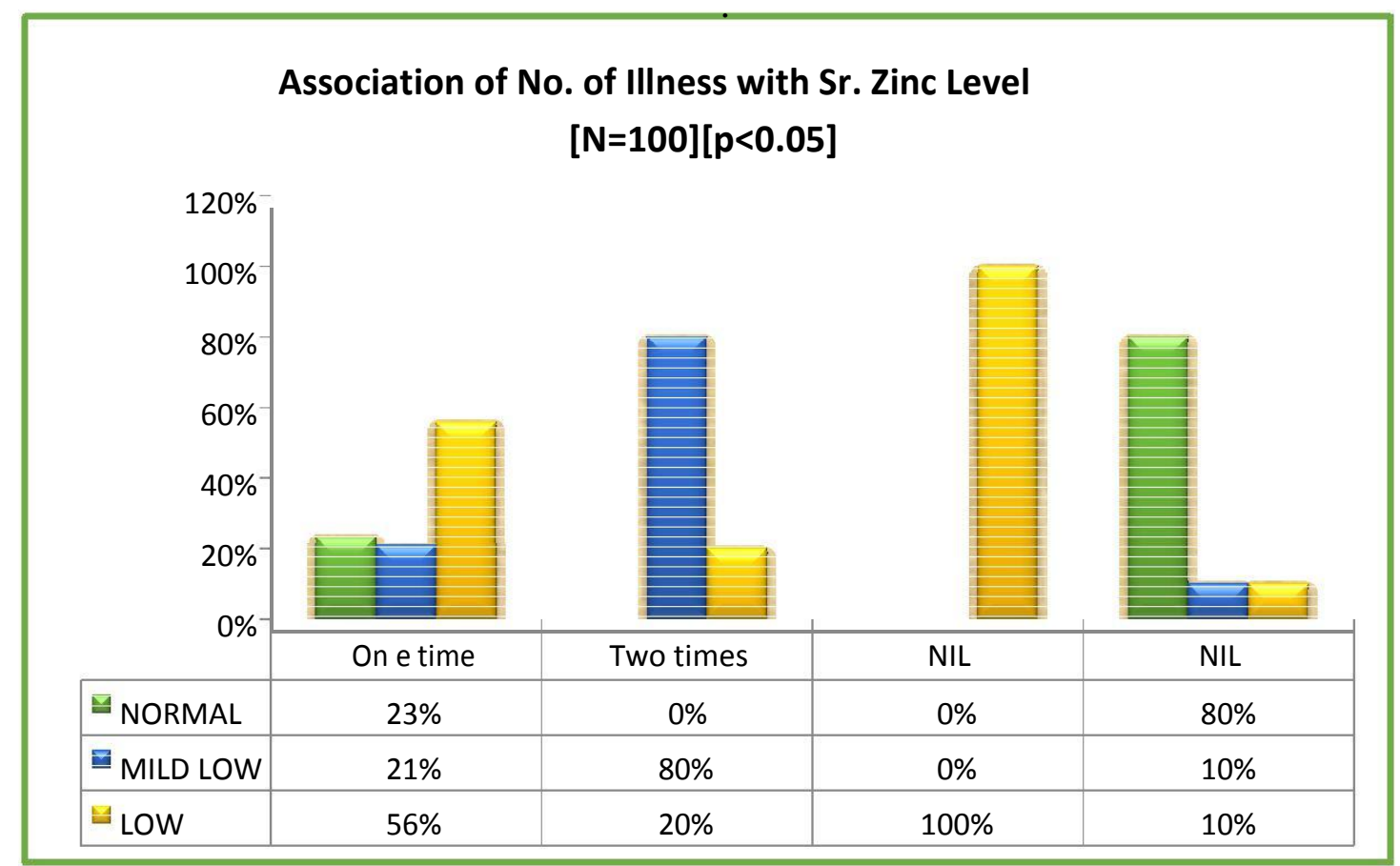

6 months

There is statistically significant association between serum zinc level and number of illnesses in last

\section{ASSOCIATI ON OF FOOD INTAKE WITH SERUM ZINC IN STUDY GROUP}

\begin{tabular}{|c|c|c|c|c|c|c|c|}
\hline \multirow{2}{*}{$\begin{array}{l}\text { STUDY } \\
\text { GROUP }\end{array}$} & \multirow[b]{2}{*}{ Intake } & \multicolumn{2}{|c|}{ Serum Zinc Level } & \multirow{2}{*}{ Low } & \multirow{2}{*}{ To tal } & \multirow{2}{*}{$(\%)$} & \multirow{2}{*}{ Sig } \\
\hline & & Normal & Mild Low & & & & \\
\hline \multirow{5}{*}{ CASES } & V eg & 2 & 7 & 13 & 22 & $44 \%$ & \\
\hline & Egg only & 0 & 4 & 3 & 7 & $14 \%$ & \\
\hline & Nonn Veg & 7 & 2 & 9 & 18 & $36 \%$ & $<0.05$ \\
\hline & NA & 1 & 0 & 2 & 3 & $6 \%$ & \\
\hline & Total & 10 & 13 & 27 & 50 & $100 \%$ & \\
\hline \multirow{5}{*}{ CONTROL } & V eg & 5 & 3 & 5 & 13 & $26 \%$ & \\
\hline & Egg only & 2 & 1 & 0 & 3 & $6 \%$ & \\
\hline & Nonn Veg & 29 & 1 & 0 & 30 & $60 \%$ & \\
\hline & NA & 4 & 0 & 0 & 4 & $8 \%$ & $<0.05$ \\
\hline & Total & 40 & 5 & 5 & 50 & $100 \%$ & \\
\hline
\end{tabular}

There is significant association between type of food intake and serum zinc levels. Low serum zinc level is associated with vegetarian diet. 


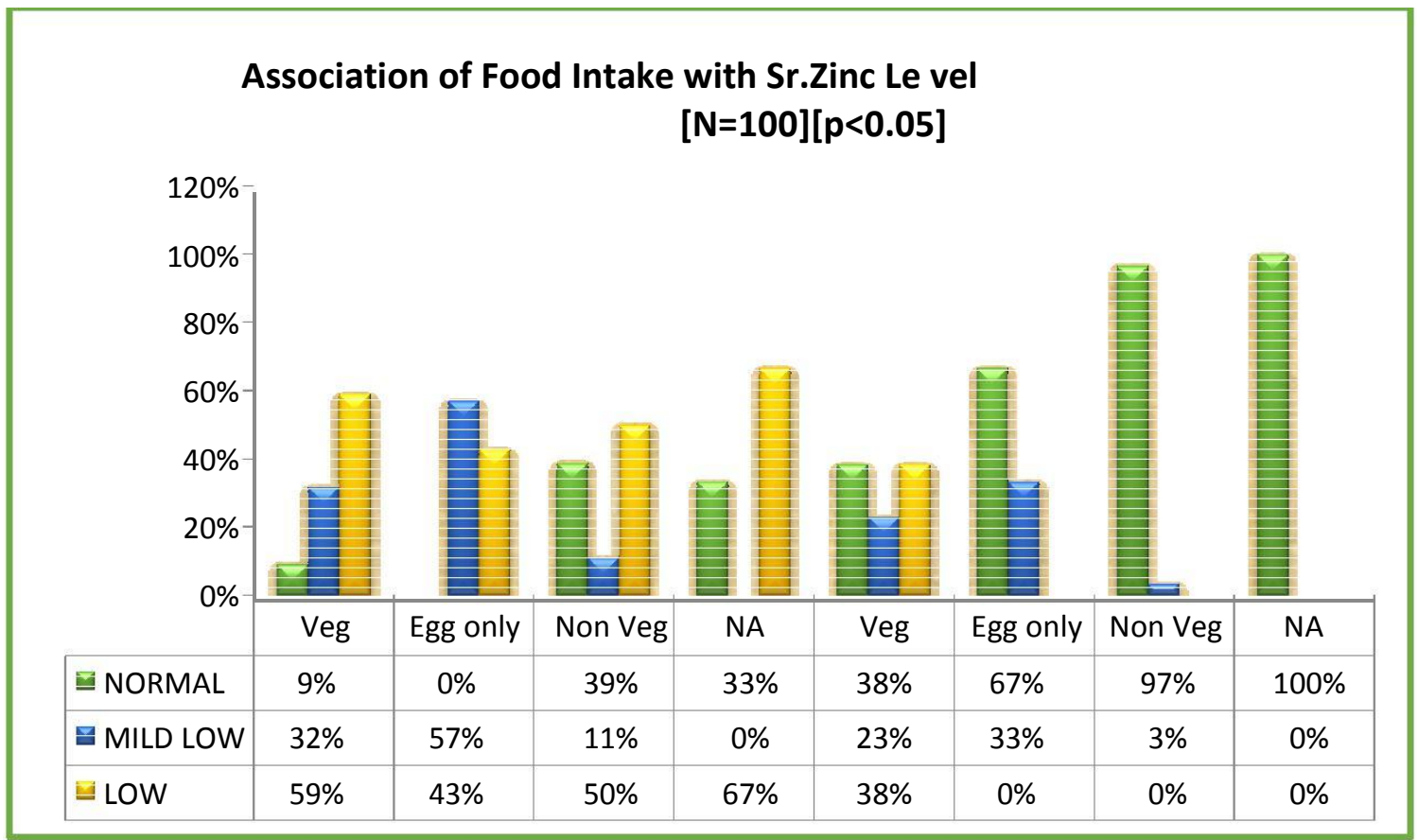

\begin{tabular}{|c|c|c|c|c|c|c|}
\hline \multicolumn{7}{|c|}{ HEART RATE WITH ZINC LEVELS } \\
\hline \multirow{2}{*}{\multicolumn{3}{|c|}{ Serum $\mathrm{Z}$ inc }} & \multicolumn{2}{|c|}{ Group } & \multirow{3}{*}{\begin{tabular}{|c|} 
Total \\
10
\end{tabular}} & \multirow{2}{*}{ Sig } \\
\hline & & & Cases & Controls & & \\
\hline \multirow{3}{*}{ Normal } & \multirow{2}{*}{ HR } & Tachycardia & 10 & 0 & & \\
\hline & & Normal & 0 & 40 & 40 & $<0.001$ \\
\hline & & Total & 10 & 40 & 50 & \\
\hline \multirow{3}{*}{$\begin{array}{l}\text { Mild } \\
\text { Low }\end{array}$} & \multirow{2}{*}{ HR } & Tachycardia & 13 & 0 & 13 & \\
\hline & & Normal & 0 & 5 & 5 & $<0.001$ \\
\hline & & Total & 13 & 5 & 18 & \\
\hline \multirow{3}{*}{ Low } & \multirow{2}{*}{ HR } & Tachycardia & 27 & 0 & 27 & \\
\hline & & Normal & 0 & 5 & 5 & $<0.001$ \\
\hline & & Total & 27 & 5 & 32 & \\
\hline
\end{tabular}




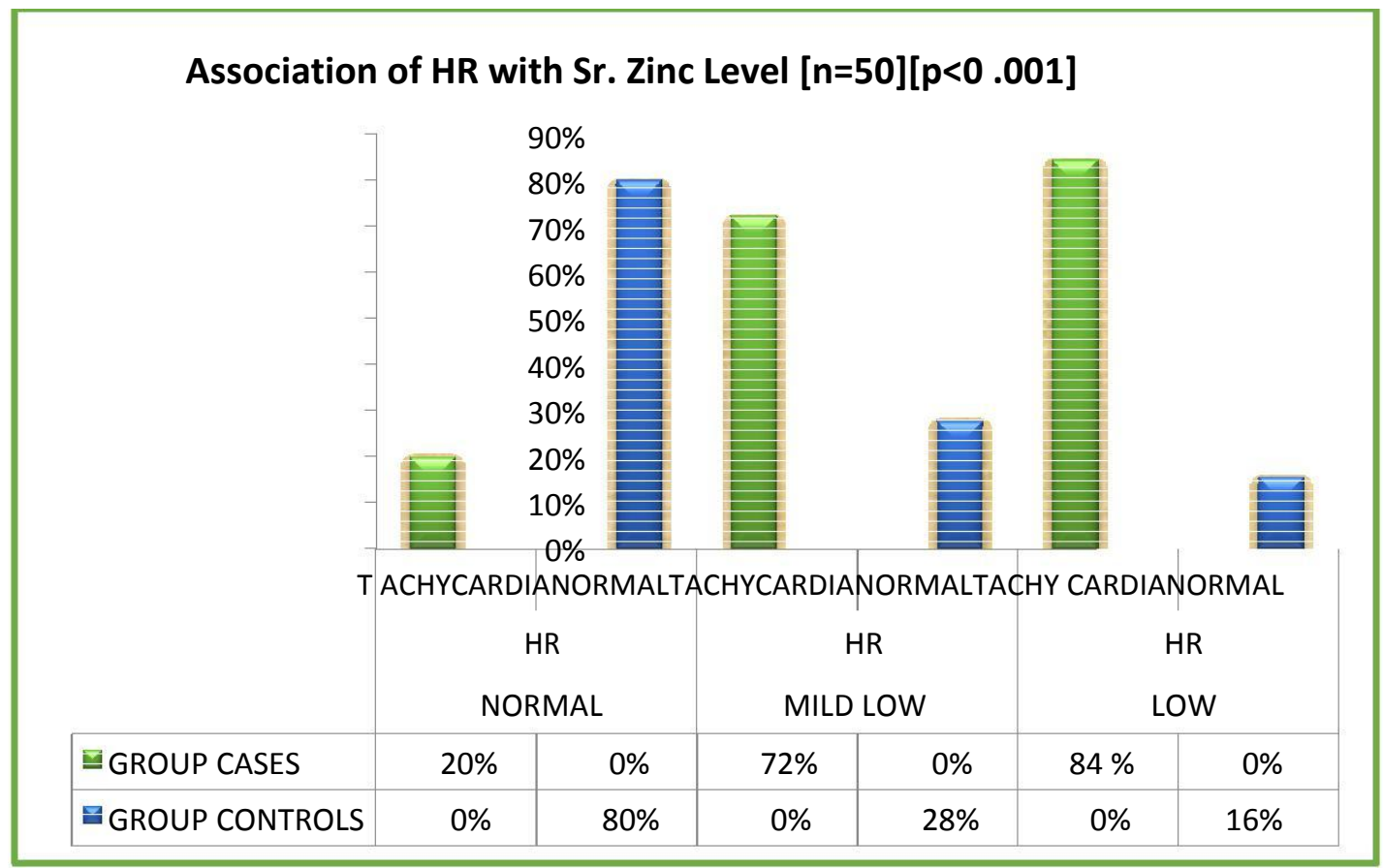

There is significant association with low serum zinc level and tachycardia.

\section{ASSOCIATION OF SERUM ZINC LEVEL WITH RESPIRATORY RATE}

\begin{tabular}{|c|c|c|c|c|c|c|}
\hline \multicolumn{7}{|c|}{ RE SPIRATORY RATE WITH Zn LEVELS } \\
\hline \multirow{2}{*}{\multicolumn{2}{|c|}{ Serum }} & \multirow{3}{*}{ Zinc } & \multirow{2}{*}{\multicolumn{2}{|c|}{ GROUP }} & \multirow{3}{*}{ Total } & \multirow{3}{*}{ Sig } \\
\hline & & & & & & \\
\hline & & & CASES & CONTROLS & & \\
\hline \multirow{3}{*}{ NORMAL } & \multirow{2}{*}{ RR } & TACHYPNEA & 10 & 0 & 10 & \\
\hline & & NORMAL & 0 & 40 & 40 & $<0.001$ \\
\hline & & Total & 10 & 40 & 50 & \\
\hline \multirow{3}{*}{ MILD LOW } & \multirow{2}{*}{ RR } & TACHYPNEA & 13 & 0 & 13 & \\
\hline & & NORMAL & 0 & 5 & 5 & $<0.001$ \\
\hline & & Total & 13 & 5 & 18 & \\
\hline \multirow{3}{*}{ LOW } & \multirow{2}{*}{ RR } & TACHYPNEA & 27 & 0 & 27 & \\
\hline & & NORMAL & 0 & 5 & 5 & $<0.001$ \\
\hline & & Total & 27 & 5 & 32 & \\
\hline
\end{tabular}

Low serum zinc level is associated with tachypnea with statistic al significance. 


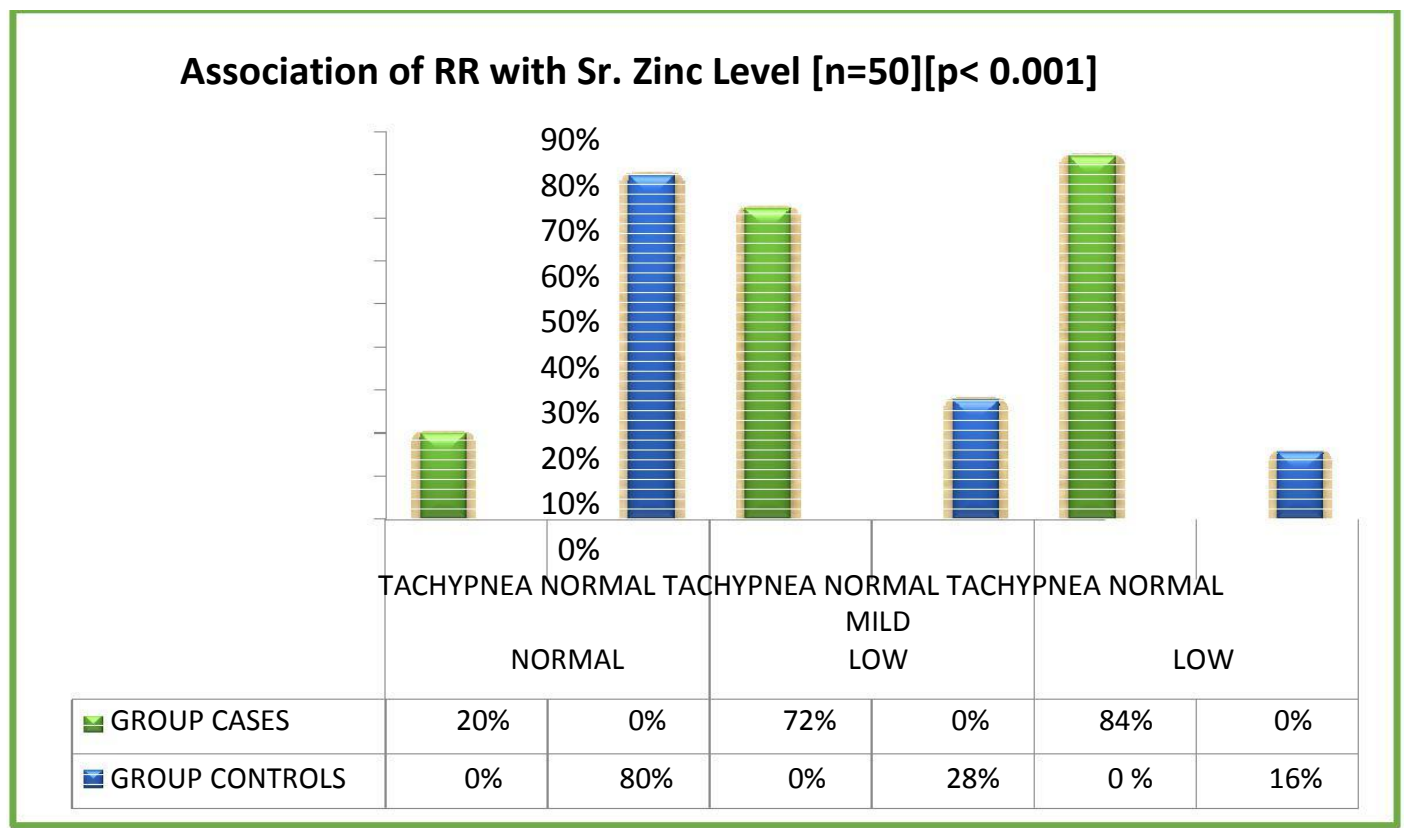

ASSOCIATI ON OF LOW SERUM ZINC LEVELS WITH OXYGEN SATURATION VALUES

\begin{tabular}{|c|c|c|c|c|c|c|c|}
\hline \multirow{2}{*}{$\begin{array}{l}\text { STUDY } \\
\text { GROUP }\end{array}$} & \multirow[b]{2}{*}{ SPO2 } & \multicolumn{2}{|c|}{ Serum Zinc Level } & \multirow{2}{*}{ Low } & \multirow{2}{*}{ Total } & \multirow{2}{*}{$(\%)$} & \multirow{2}{*}{ Sig } \\
\hline & & Normal & Mild Low & & & & \\
\hline \multirow{4}{*}{ CASES } & $>92 \%$ & 10 & 2 & 2 & 14 & $28 \%$ & \\
\hline & $<92 \%$ & 0 & 4 & 6 & 10 & $20 \%$ & \\
\hline & $<90 \%$ & 0 & 7 & 19 & 26 & $52 \%$ & $<0.001$ \\
\hline & Total & 10 & 13 & 27 & 50 & $100 \%$ & \\
\hline
\end{tabular}

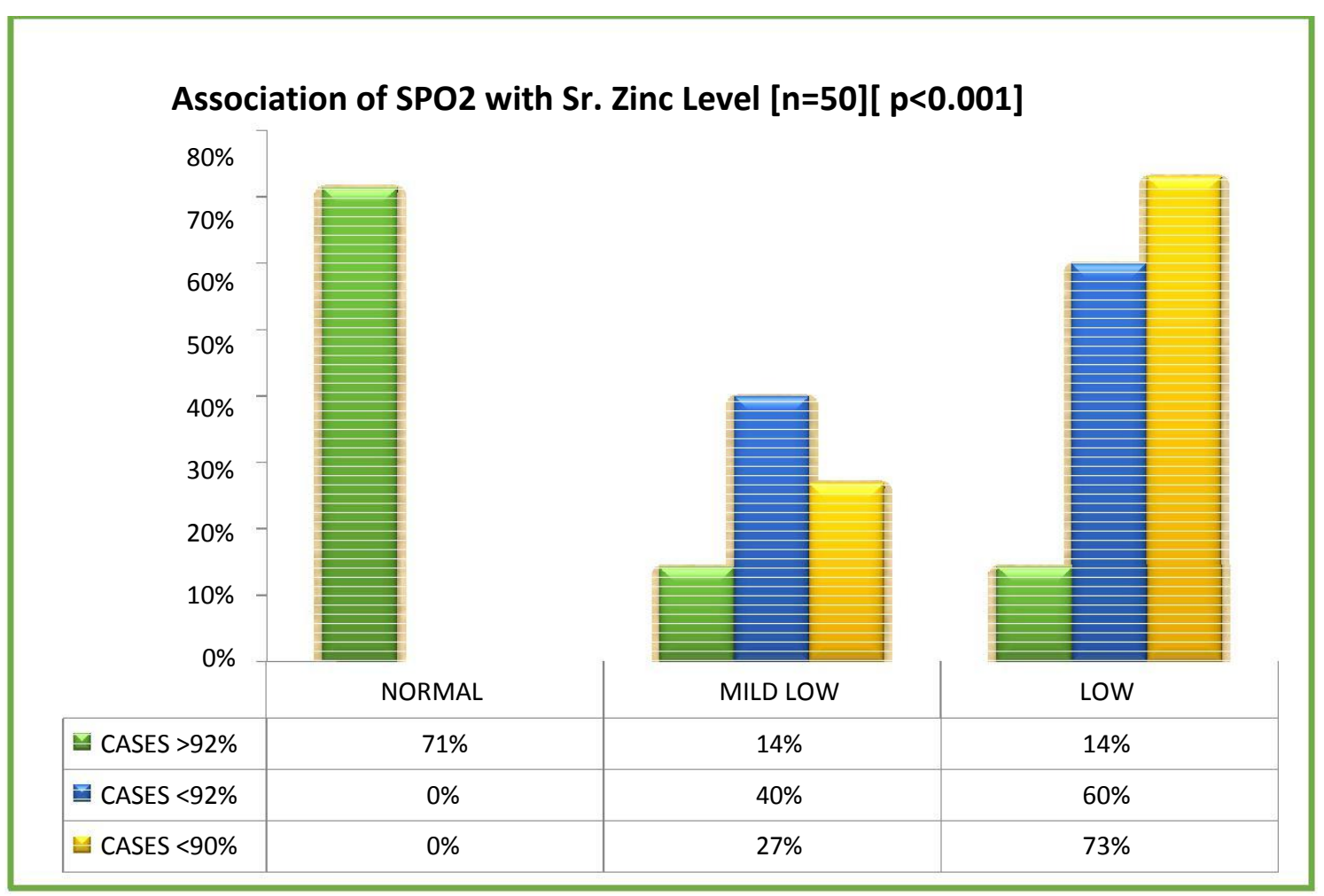


In this stud y there is significant association between low serum zinc level and low oxygen saturation

ASSOCIATION OF LEUCOCYTOSIS WITH LOW SERUM ZINC LEVELS

\begin{tabular}{|c|c|c|c|c|c|c|c|}
\hline \multirow{2}{*}{$\begin{array}{l}\text { STUDY } \\
\text { GROUP }\end{array}$} & \multirow{2}{*}{ Leucocy tosis } & \multicolumn{2}{|c|}{ Serum Zinc Level } & \multirow{2}{*}{ Low } & \multirow{2}{*}{ Tot al } & \multirow{2}{*}{$(\%)$} & \multirow{2}{*}{ Sig } \\
\hline & & Normal & Mild Low & & & & \\
\hline \multirow{3}{*}{ CASES } & Present & 3 & 6 & 20 & 29 & $58 \%$ & \\
\hline & Absent & 7 & 7 & 7 & 21 & $42 \%$ & $<0.05$ \\
\hline & Tot al & 10 & 13 & 27 & 50 & $100 \%$ & \\
\hline
\end{tabular}

There is significant association between low serum zinc levels and leucocytosis. This is may be due to defective immune mechanism associated with low level of zinc.

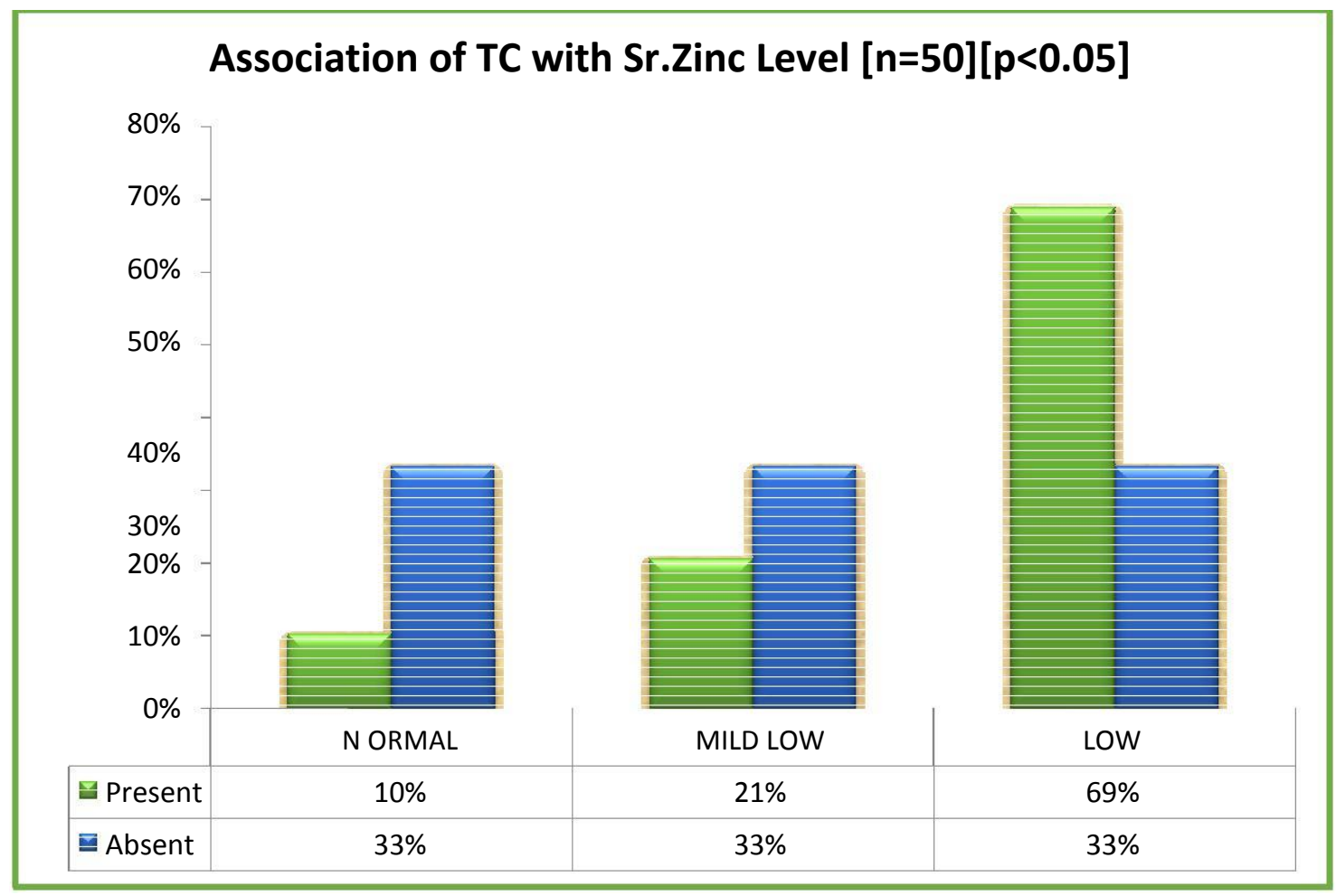

\section{DISCUSSION}

This study is a case control study involving 50 cases and 50 controls. All age, sex and nutrition matched controls. Age group taken was from 6 months to 5 years. Among the study group, $68 \%$ belong to age less than 2 years. Malnourished children as per exclusion criteria are excluded. As the majority study group belongs to age less than 2 years, this has impact on food intake, and no association could be made between tuber intake and low serum zinc level. In this study there is strong association between severe pneumonia(both lobar and bronchopneumonia) and low serum zinc level which is similar to study done by Md. Salin shakur, et al, 2003; and study by Saket Kumar, et al in 2003; and study by Secil Arica, et al in 2011. Also lower the serum zinc level the higher the respiratory distress and associated with lower saturation levels which is similar to study by Hanaa I. Rady, et al in 2013. In our study there was a slight predominance of male cases, which was also recorded in various other studies. This was explained by the fact of increased concern over the male children than the female children. In this study there was a significant association between febrile seizure and low serum zinc level as noticed in various other studies.

\section{SUMMARY}

Serum zinc levels in children with severe pneumonia are low $(\mathrm{P}=0.001)$. About $80 \%$ of 
children with severe pneumonia had low serum zinc levels. A slight preponderance of male is seen in the study group, probably social reasons which give more attention to male child may be the reason. In this study group no association between low serum zinc level and variables like age, sex, place of residence, duration of breast feeding, time of weaning, preterm/twin pregnancy, calorie and protein gap were noted. Also there was no significant association between low serum zinc level and developmental milestones, immunization history and family history of seizures. There was strong association between low serum zinc level and mixed feeds. So exclusive breast feeding seems to be protective against zinc deficiency. Low birth weight has strong association with low serum zinc level. Low serum zinc levels have significant association with febrile seizures. Increased frequency of illness in past 6 months is associated with low serum zinc levels. Strong association of low serum zinc levels with vegetarian diet. Non vegetarian diet is protective against zinc deficiency. As $68 \%$ of study population is less than 2 years of age, intake of tubers does not have significant association with low serum zinc level. In this study low serum zinc is associated with tachypnea, increased respiratory distress and low oxygen saturation. Also low serum zinc level is associated with leucocytosis significantly and this may be due to increased susceptibility to infection. Low serum zinc level does not have significant association with type of pneumonia that is lobar pneumonia or bronchopneumonia. There is no association between low serum zinc level and hospital stay. This may be due to appropriate antibiotics and supportive measures used to treat pneumonia.

\section{CONCLUSION}

In conclusion, children with severe pneumonia have low serum zinc levels and thus "Low serum zinc level is a marker of severe pneumonia. Also lower the serum zinc level the higher the respiratory distress and associated significantly with low oxygen saturation.

\section{REFERENCE}

1. Saeed Akhtar.Zinc status in south asian populations - an update.J Health popul nutr 2013 June; 31(2):139-149”'World health organisation Pneumonia fact sheet N331, November 2014.

2. Sandora, Thomas J, and Theodore C.Sectish, Community acquired pneumonia" Nelson textbook of Paediatrics, 2011.

3. Sandstead HH. Understanding zinc: recent observations and interpretations. J Lab Clin Med 1994;124: 322-7.

4. Institute of Medicine, Food and Nutrition Board. Dietary Reference Intakes for Vitamin A, Vitamin K, Arsenic, Boron, Chromium, Copper, Iodine, Iron, Manganese, Molybdenum, Nickel, Silicon, Vanadium, and Zinc. Washington, DC: National Academy Press, 2001.

5. Solomons NW. Mild human zinc deficiency produces an imbalance between cellmediated and humoral immunity. Nutr Rev 1998;56: 27-8.

6. Heyneman CA. Zinc deficiency and taste disorders. Ann Pharmacother1996;30:186-7.

7. Fabris N, Mocchegiani E. Zinc, human diseases and aging. Aging (Milano) 1995;7:77-93

8. Maret W, Sandstead HH. Zinc requirements and the risks and benefits of zinc supplementation. J Trace Elem Med Biol 2006;20:3-18.

9. Prasad AS, Beck FW, Grabowski SM, Kaplan J, Mathog RH. Zinc deficiency: changes in cytokine production and T-cell subpopulations in patients with head and neck cancer and in noncancer subjects. Proc Assoc Am Physicians 1997;109:68-77.

10. Rink L, Gabriel P. Zinc and the immune system. Proc Nutr Soc 2000;59:541-52.

11. U.S. Department of Agriculture, Agricultural Research Service. 2011. USDA National Nutrient Database for Standard Reference, Release 24. Nutrient Data Laboratory Home Page,http://www.ars.usda.gov/ba/bhnrc/ndl

12. Sandstrom B. Bioavailability of zinc. Eur $\mathbf{J}$ Clin Nutr 1997;51 (1 Suppl):S17-9. 
13. Wise A. Phytate and zinc bioavailability. Int J Food Sci Nutr 1995;46:53-63.

14. Jafek BW, Linschoten MR, Murrow BW. Anosmia after intranasal zinc gluconate use. Am J Rhinol 2004;18:137-41

15. Alexander TH, Davidson TM. Intranasal zinc and anosmia: the zinc-induced anosmia syndrome. Laryngoscope 2006;116:217-20.

16. Alaimo K, McDowell MA, Briefel RR, et al. Dietary intake of vitamins, minerals, and fiber of persons ages 2 months and over in the United States: Third National Health and Nutrition Examination Survey, Phase 1, 1986-91. Advance data from vital and health statistics no 258. Hyattsville, Maryland: National Center for Health Statistics. 1994.

17. Interagency Board for Nutrition Monitoring and Related Research. Third Report on Nutrition Monitoring in the United States. Washington, DC: U.S. Government Printing Office, 1995.

18. Hambidge KM, Mild zinc deficiency in human subjects. In: Mills CF, ed. Zinc in Human Biology. New York, NY: SpringerVerlag, 1989:281-96.

19. King JC, Cousins RJ. Zinc. In: Shils ME, Shike M, Ross AC, Caballero B, Cousins, RJ, eds. Modern Nutrition in Health and Disease, 10th ed. Baltimore, MD: Lippincott Williams \& Wilkins, 2005:271-85.

20. Krasovec M, Frenk E. Acrodermatitis enteropathica secondary to Crohn's disease. Dermatology 1996;193:361-3.

21. Ploysangam A, Falciglia GA, Brehm BJ. Effect of marginal zinc deficiency on human growth and development. J Trop Pediatr 1997;43:192-8.

22. Nishi Y. Zinc and growth. J Am Coll Nutr 1996;15:340-4.

23. Hunt JR. Bioavailability of iron, zinc, and other trace minerals from vegetarian diets. Am J Clin Nutr 2003;78 (3 Suppl):633S-9S.

24. Van Wouwe JP. Clinical and laboratory assessment of zinc deficiency in Dutch children. A review. Biol Trace Elem Res 1995;49:211-25.

25. Hambidge KM, Krebs NF. Zinc deficiency: a special challenge. J Nutr 2007; 137:11015. [PubMed abstract]

26. Prasad AS. Zinc deficiency in women, infants and children. J Am Coll Nutr 1996;15:113-20.

27. Naber TH, van den Hamer CJ, Baadenhuysen H, Jansen JB. The value of methods to determine zinc deficiency in patients with Crohn's disease. Scand J Gastroenterol 1998;33:514-23.

28. Valberg LS, Flanagan PR, Kertesz A, Bondy DC. Zinc absorption in inflammatory bowel disease. Dig Dis Sci. 1986 Jul;31(7):724-31.

29. Prasad AS. Zinc deficiency. BMJ 2003;326:409-10

30. American Dietetic Association, Dietitians of Canada. Position of the American Dietetic Association and Dietitians of Canada: vegetarian diets. J Am Diet Assoc 2003;103: 748-65.

31. Caulfield LE, Zavaleta N, Shankar AH, Merialdi M. Potential contribution of maternal zinc supplementation during pregnancy to maternal and child survival. Am J Clin Nutr 1998; 68 (2 Suppl):499S$508 \mathrm{~S}$.

32. Krebs NF. Zinc supplementation during lactation. Am J Clin Nutr 1998;68 (2 Suppl):509S -12S.

33. Brown KH, Allen LH, Peerson J. Zinc supplementation and children's growth: a meta-analysis of intervention trials. Bibl Nutr Dieta 1998; 54:73-6.

34. Leonard MB, Zemel BS, Kawchak DA, Ohene-Frempong K, Stallings VA. Plasma zinc status, growth, and maturation in children with sickle cell disease. J Pediatr 1998;132:467-71

35. Zemel BS, Kawchak DA, Fung EB, OheneFrempong K, Stallings VA. Effect of zinc supplementation on growth and body 
composition in children with sickle cell disease. Am J Clin Nutr 2002;75:300-7.

36. Prasad AS. Zinc deficiency in patients with sickle cell disease. Am J Clin Nutr 2002;75: 181-2.

37. Kang YJ, Zhou Z. Zinc prevention and treatment of alcoholic liver disease. Mol Aspects Med 2005;26: 391-404.

38. Menzano E, Carlen PL. Zinc deficiency and corticosteroids in the pathogenesis of alcoholic brain dysfunction review. Alcohol Clin Exp Res 1994;18:895-901.

39. Shankar AH, Prasad AS. Zinc and immune function: the biological basis of altered resistance to infection. Am $\mathrm{J}$ Clin Nutr 1998;68:447S-63S.

40. Wintergerst ES, Maggini S, Hornig DH. Contribution of selected vitamins and trace elements to immune function. Ann Nutr Metab 2007; 51:301-23.

41. Prasad AS. Effects of zinc deficiency on Th1 and Th2 cytokine shifts. J Infect Dis 2000;182 (Suppl):S62-8.

42. Brooks WA, Santosham M, Naheed A, Goswami D, Wahed MA, Diener-West M, et al. Effect of weekly zinc supplements on incidence of pneumonia and diarrhoea in children younger than 2 years in an urban, low-income population in Bangladesh: randomised controlled trial. Lancet 2005;366: 999-1004.

43. Hulisz D. Efficacy of zinc against common cold viruses: an overview. J Am Pharm Assoc (2003) 2004; 44:594-603.

44. Caruso TJ, Prober CG, Gwaltney JM Jr. Treatment of naturally acquired common colds with zinc: a structured review. Clin Infect Dis 2007; 45:569-74.

45. Willis MS, Monaghan SA, Miller ML, McKenna RW, Perkins WD, Levinson BS, et al. Zinc-induced copper deficiency: a report of three cases initially recognized on bone marrow examination. Am J Clin Pathol 2005;123:125-31.
46. Lewis MR, Kokan L. Zinc gluconate: acute ingestion. J Toxicol Clin Toxicol 1998; 36: 99-101. 